\title{
Sizing and Study of the Energy Production of a Grid-tied Photovoltaic System Using PVsyst Software
}

\author{
Dimensionado y estudio de la producción energética de un \\ Sistema fotovoltaico grid-tied utilizando software pvsyst \\ Yecid Muñoz $^{1 *}$, Orlando Vargas ${ }^{1}$, Gustavo Pinilla ${ }^{1}$, Jairo Vasquez ${ }^{1}$ \\ ${ }^{1}$ Universidad Antonio Nariño. Bucaramanga, Colombia.
}

\begin{abstract}
This paper describes analyses carried out on the sizing and simulation of a grid-tied photovoltaic system in Bucaramanga, Colombia with the virtual tool PVsyst. The simulation was primarily performed in order to understand the behavior of gridtied photovoltaic installations at a specific location, while avoiding the oversizing or undersizing of the systems, thus projecting installations which better approximate real conditions. Theoretical calculations were performed conventionally in order to make comparisons of calculated data with simulation results. We highlight the good potential of the studied area, with $1882 \mathrm{kWh} / \mathrm{m}^{2}$ at optimal orientation, which would generate $1375 \mathrm{kWh} /$ year for a $1 \mathrm{~kW}$ PV system, with a yield factor of $72.7 \%$. Losses are disaggregated in this paper, including a study of the behavior associated with the tilt and orientation of the system. Such information on potential and performance is a valuable reference for any possible sizing of photovoltaic projects at similar latitudes
\end{abstract}

Keywords: Performance Ratio, PVsyst software, photovoltaic production, system performance, system losses.

\section{Resumen}

Este artículo describe los análisis efectuados mediante el dimensionamiento y simulación de un sistema fotovoltaico conectado a red ubicado en Bucaramanga Colombia., a través de la herramienta virtual PVSYST. La simulación se realiza fundamentalmente para conocer el comportamiento de las instalaciones fotovoltaicas conectadas a red, en una ubicación específica, evitando sobredimensionar o subdimensionar los sistemas, proyectando así instalaciones con una gran aproximación a condiciones reales. Se realizaron cálculos teóricos de forma convencional con el objeto de efectuar comparaciones de datos calculados con resultados de la simulación. Dentro de los resultados obtenidos se destaca el buen potencial de la zona estudiada, con $1882 \mathrm{Kwh} / \mathrm{m}^{2}$ en orientación óptima, que para una instalación fotovoltaica de $1 \mathrm{Kw}$, generaría unos $1375 \mathrm{Kwh} / \mathrm{año}$, con un factor de rendimiento del 72,7\%, cuyas pérdidas son desagregadas en el desarrollo del documento, incluyendo, un estudio del comportamiento asociado a la inclinación y orientación del sistema. Este tipo de información, sobre potencial y desempeño, es una valiosa referencia, para el dimensionado de proyectos fotovoltaicos que se deseen realizar en latitudes cercanas a la del presente estudio.

Palabras clave: Performance Ratio, software PV-Syst, producción fotovoltaica, rendimiento del sistema, pérdidas.

*Corresponding Author.

E-mail: yecidmaldonado@uan.edu.co
How to cite: Molina, V., Cuadra, M. Martínez, L. J., Robles, H. V., Sizing and Study of the Energy Production of a Grid-tied Photovoltaic System Using PVsyst Software, TECCIENCIA, Vol. 12 No. 22., 27-32, 2017

DOI: http:/dx.doi.org/10.18180/Tecciencia.2017.22.24 


\section{TECCIENCIA}

\section{Introduction}

Photovoltaic solar energy is the direct conversion of solar radiation into electricity through photovoltaic cells. These are manufactured with crystalline semiconductor materials which, due to the photovoltaic effect, generate electric current when exposed to solar radiation. Photovoltaic panels are composed of a grouping of cells [1]. This type of energy, like other renewable energies, is inexhaustible, clean, respects the environment, and establishes a basis for self-supply.

The study and optimization of the performance of this renewable source has the great potential to reduce greenhouse gases emissions, especially $\mathrm{CO}_{2}$, thus helping to fulfill the commitments assumed in the Kyoto Protocol, which aims to reduce greenhouse gas emissions and protect the planet from climate change.

The electric current generated from solar photovoltaic energy currently has a variety of applications, primarily in isolated systems and systems connected to the grid, called grid-tied systems [2]. The focus of this study is grid-tied systems for a nominal $1 \mathrm{~kW}$ installation.

The PVsyst software application allows for the design, simulation, and data analysis of a photovoltaic system. It includes meteorological data from the most-used international databases, such as NASA, SSE RETScreen, and Meteonorm. This is essential for the calculation of an installation at our location, because in many cases the PVsyst program will not have data about the location where the photovoltaic generator is to be installed.

\section{Grid-Tied PV System Sizing}

Generally speaking, a photovoltaic system connected to a SFCR network can capture solar energy, convert it into electricity, and transform it into alternating current with the same characteristics as the AC grid [3]. To do this, optimum sizing is necessary for its elements to achieve synergy in their operation. Thus, the elements have to adapt to objectives of power, space, the climatic conditions of the area, and the objectives of produced energy (to either be completely consumed or delivered to the grid). In this context, a generator, consisting of a set of photovoltaic panels, is used, in addition to a grid inverter, which converts the DC power from the PV array to AC power to be transformed to allow correct grid coupling, as shown in Figure $1[4]$.
Figure 1. Basic diagram of a grid-tied photovoltaic system. Courtesy of the Sun Water Project.

\subsection{Components:}

The components of a photovoltaic system, shown in Figure 1 , are detailed below. The main element is the photovoltaic array, which consists of the electrical interconnection of solar modules in such a way that the supplied voltage and current increase to match the desired value. The main sizing factor for the photovoltaic array is the power to be installed. This depends on the area available, the load curve that energy can consume, and whether it is possible to deliver this energy to the public grid. Solar panel types are classified, according to manufacturing technology, into monocrystalline, polycrystalline, or thin film [5]. For this study, we selected polycrystalline modules due to their high efficiency and good performance under the influence of temperature.

A DC/AC power inverter converts the direct current produced by the photovoltaic generator into alternating current, fulfilling certain requirements of effective voltage, voltage wave frequency, and current. All of these parameters are synchronized with the local power grid [6]. Protection boxes ensure the safety of the grid-tied PV system and electrical safety [7].

Determination of the power of the PV system: We chose as reference a nominal power of $1-\mathrm{kW}$ peak in order to carry out the analysis since this power value can quickly relate the calculation variables to the grid-tied systems.

Selection of the Photovoltaic module: We selected polycrystalline modules, due to their greater efficiency and offer of the best performance under the influence of temperature. According to the area available we decided to use four 250 Watts peak module units to form the photovoltaic array.

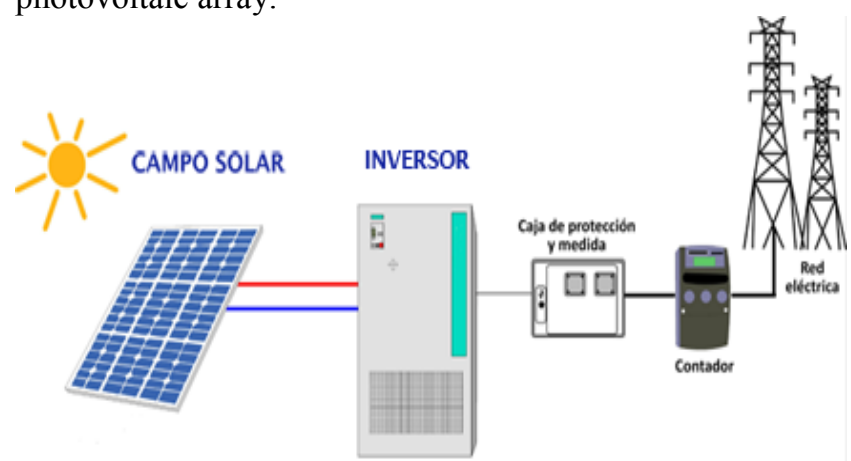

Figure 1. Basic diagram of a grid-tied photovoltaic system. Courtesy of the Sun Water Project. 


\section{TECCIENCIA}

Inverter selection: According to the electrical characteristics determined by the photovoltaic array, there are requirements for an inverter of $1-\mathrm{kW}$ nominal power, $69.8 \mathrm{~V}, 14.36 \mathrm{~A}$ in $\mathrm{DC}$ and $120 \mathrm{~V}$ in $\mathrm{AC}, 60 \mathrm{~Hz}$ single phase, and a network connection.

Installation location: The geographical location for the site of the grid-tied solar photovoltaic installation is in the metropolitan area of Bucaramanga, Colombia, whose geographical coordinates are:

Latitude: 7.035258

Altitude: 907 m.s.n.m.

Longitude: -73.109584

Database: The solar radiation data for the photovoltaic generator location were downloaded from NASA's data bank, accessed by RETSCREEN software. In the table below we describe in detail the information obtained

Table 1. Irradiation, temperature, and wind speed; monthly average in Bucaramanga

\begin{tabular}{|l|l|l|l|l|}
\hline & $\begin{array}{l}\text { Global } \\
\text { Irradiati } \\
\text { on }\end{array}$ & $\begin{array}{l}\text { Air } \\
\text { Temperat } \\
\text { ure }\end{array}$ & $\begin{array}{l}\text { Wind } \\
\text { Speed }\end{array}$ & $\begin{array}{l}\text { Earth } \\
\text { Tempera } \\
\text { ture }\end{array}$ \\
\hline January & 5.34 & 23.3 & 2 & 24.3 \\
\hline February & 5.34 & 24.7 & 1.9 & 26.4 \\
\hline March & 5.28 & 24.5 & 1.7 & 26.2 \\
\hline April & 4.96 & 23.7 & 1.6 & 24.9 \\
\hline May & 5.01 & 23.2 & 1.6 & 23.9 \\
\hline June & 5.16 & 23.1 & 1.8 & 23.6 \\
\hline July & 5.57 & 23.4 & 1.8 & 24 \\
\hline August & 5.55 & 23.6 & 1.6 & 24.4 \\
\hline $\begin{array}{l}\text { Septemb } \\
\text { er }\end{array}$ & 5.27 & 23 & 1.5 & 23.8 \\
\hline October & 4.8 & 22.4 & 1.5 & 23.2 \\
\hline $\begin{array}{l}\text { Novemb } \\
\text { er }\end{array}$ & 4.72 & 22.3 & 1.5 & 23 \\
\hline $\begin{array}{l}\text { Decembe } \\
\text { r }\end{array}$ & 4.86 & 22.4 & 1.9 & 22.8 \\
\hline $\begin{array}{l}\text { Multiann } \\
\text { ual } \\
\text { Average }\end{array}$ & 5.2 & 23.3 & 1.7 & 24.2 \\
\hline
\end{tabular}

Energy study of grid-tied photovoltaic systems: Using the information provided by the NASA's meteorological database, a quick and reliable calculation can be made, assuming the global irradiation data is on a horizontal surface $\mathrm{G}_{\mathrm{a}}(0)$ and the radiation captured by the photovoltaic modules is on an tilted plane $\mathrm{G}_{\mathrm{a}}\left(\beta_{\text {opt }}\right)$.

First the annual global irradiation is calculated, in $\mathrm{kWh} / \mathrm{m}^{2} /$ year. We took the average daily value and multiplied it by 365 days, which gave us a result of 1898 $\mathrm{kWh} / \mathrm{m}^{2}$.

The tilt of the optimal surface $\beta_{\text {opt. }}$ faces south and is related to the latitude $\varnothing$ with the expression: $\beta_{\mathrm{opt}}=3.7+0.69 * \varnothing,=8.55^{\circ}$

Using the annual global irradiation on a horizontal plane, the incident at optimum orientation is calculated:

$$
\begin{gathered}
\mathrm{G}_{\mathrm{a}}(0) / \mathrm{G}_{\mathrm{a}}\left(\beta_{\text {opt }}\right)=1-4.46 * 10^{-4} \cdot \beta_{\text {opt }}-1.19^{*} 10^{-4} \cdot\left(\beta_{\text {opt }}\right)^{2} \\
=0.9875 \\
\mathrm{G}_{\mathrm{a}}\left(\beta_{\mathrm{opt}}\right)=18898 / 0.9875=1922.03 \mathrm{kWh} / \mathrm{m}^{2}
\end{gathered}
$$

With this result we obtain the effective annual incident irradiation in the plane of the array:

$\mathrm{G}_{\text {efa }}(\beta, \alpha) / \mathrm{G}_{\mathrm{a}}\left(\beta_{\mathrm{opt}}\right)=\mathrm{g} 1 *\left(\beta-\beta_{\mathrm{opt}}\right)^{2}+\mathrm{g} 2\left(\beta-\beta_{\mathrm{opt}}\right)+\mathrm{g} 3$.

Values from the coefficients g1, g2, and g3 correspond to a medium level of impurity [5].

$\mathrm{G}_{\text {efa }}(\beta, \alpha) / \mathrm{G}_{\mathrm{a}}\left(\beta_{\text {opt }}\right)=1.218^{*} 10^{-4}(8-8.55)^{2}+2.892 * 10^{-4}(8-$ $8.55)+0.9314=0.931$

Then: $\quad \mathrm{G}_{\mathrm{efa}}(\beta, \alpha)=0.931 * 1922.03=1789.4 \mathrm{kWh} / \mathrm{m}^{2}$.

The energy produced by a grid-tied system $\mathrm{E}_{\mathrm{AC}}$ in an annual period can be roughly estimated with the following equation:

$E_{A C}=P_{G}\left[G_{\text {efa }}(\beta, \alpha)\right] * P R *(1-F S)$

Where $P_{G}$ is the nominal power of the PV generator $(k W p)$, $\mathrm{PR}$ is the Performance Ratio, and FS is the shading factor. The latter are two dimensionless parameters.

$\mathrm{E}_{\mathrm{AC}}=1 \mathrm{kWp} * 1789.4 \mathrm{kWh} / \mathrm{m}^{2} * 0.74 *(1-0.02)=1297.7$ $\mathrm{kWh} /$ year.

\section{Simulation in Pysyst Software}

PVsyst software has been selected for its internationallyrecognized trustworthiness. Researchers around the world [8-10] have used it for the sizing and study of photovoltaic system performance. The simulation method used in the program is based on the realization of hourly energy balances throughout a year, by tracking the behavior of the system in order to calculate the appropriate combination for obtaining a system with the maximum amount of energy, in function of climactic variables such as global radiation, wind speed, and temperature, taking into account the installed capacity of the photovoltaic system.

A database associated with the software was used. It contains a variety of parameters and irradiation data collected in numerous parts of the world over the course of a year, as well as a vast gallery of photovoltaic components provided by the manufacturers in order to perform accurate simulations of the installation. 


\section{TECCIENCIA}

PVsyst allows designs at different levels.

The Pre-sized level makes a quick assessment of the dimensions of the system and its components. It likewise evaluates system production.

The Design level of the project makes a detailed simulation with hourly values, permitting the definition of the photovoltaic field and the correct selection of components.

At the Database level, PVsyst has radiation data from a large number of cities. We have the option to enter this information in from any external database, either manually or automatically. The radiation data for this specific location was imported from the NASA SSE RETScreen database. It only requires entering in the geographical coordinates and it automatically imports the meteorological information required for the photovoltaic project. In addition, the database has an extensive library of photovoltaic components with general characteristics and technical information supplied by the manufacturers.

The Tools level presents a wide range of digital aids for the climate database, components database, and data measured in order to facilitate the analysis and behavior of photovoltaic systems. Below, the main aspects considered when performing the PVsyst simulation are presented.

Figure 2 shows the effect of varying the tilt angles, azimuth, and a zone of $8 \mathrm{~N}$ latitude. It appeared that an tilt equal to the latitude and an azimuth of $0^{\circ}$ generate the least amount of losses

Figure 3 shows the trajectory decomposed into angles and the movement of the sun. Based on the tilt and azimuth values, we can observe the solar incidence in the PV modules.

Figure 4 reflect how the irradiance primarily affects the current in a direct relationship. At a higher irradiance, the photovoltaic module provides a higher intensity.

A different behavior appears with temperature variations. The short circuit current is independent of the temperature variation, while the open-circuit voltage and the maximum power decrease as temperature increases $\left(-0.45 \% \mathrm{~W} /{ }^{\circ} \mathrm{C}\right)$. Another aspect to be considered in the simulation is the efficiency curve of the grid-connected inverter, because depending on the operating point (placed by the power delivered by the field of PV panels), the inverter operates with differing efficiency. This variation in efficiency will have a significant influence on the energy performance of the system. Figure 5 shows the efficiency curve, according to power input, for the $1 \mathrm{~kW}$ inverter. This curve was taken from the PVsyst library, and has been utilized in this simulation.
Incl. $8^{\circ}$

Acimut $0^{\circ}$
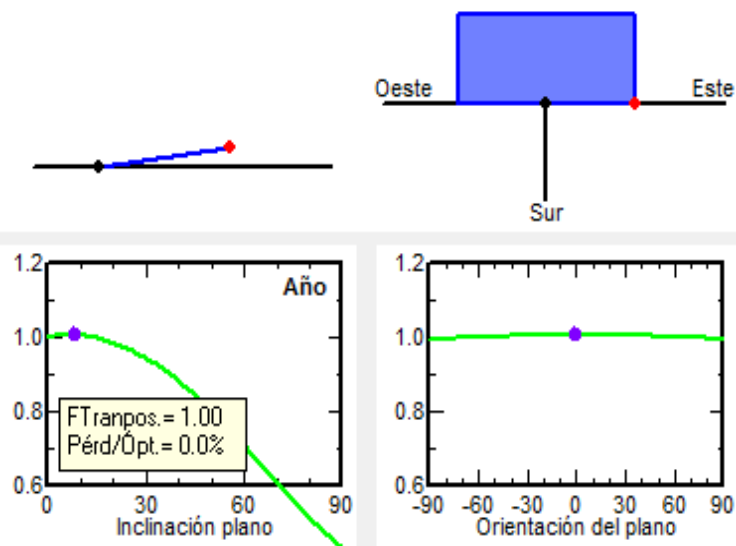

Figure 2 Orientation of photovoltaic modules

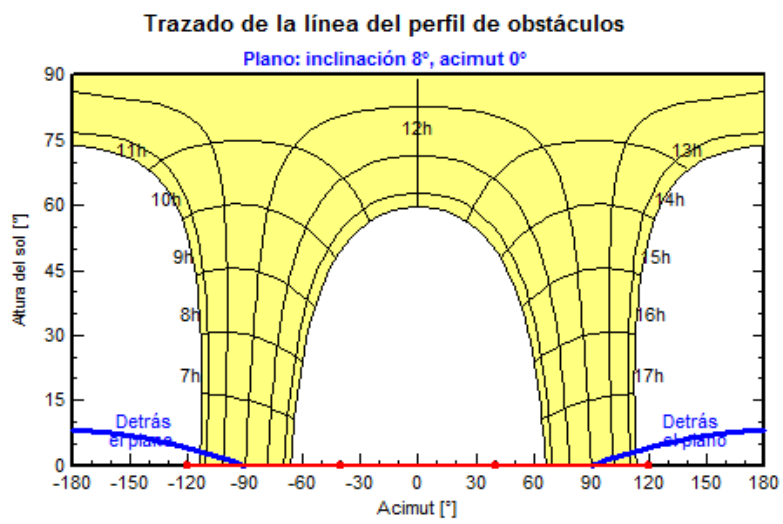

Figure 3 Sun path and horizon profile

Módulo FV: Upsolar, UP-M250P-B

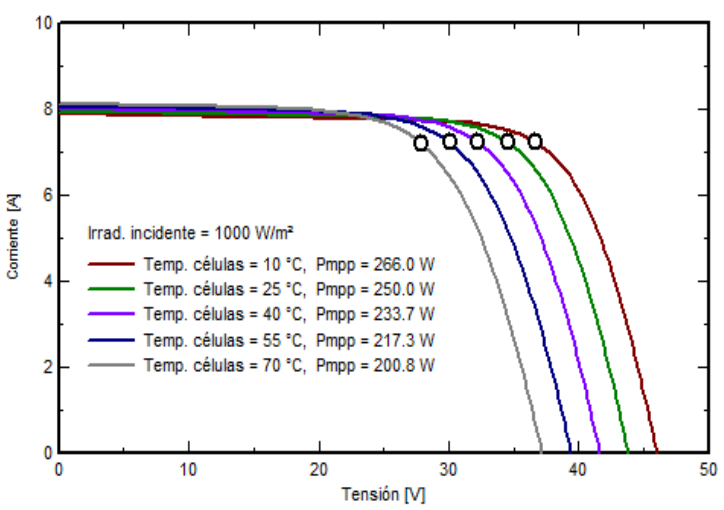

Figure 4. Performance of the module based on incident irradiance and temperature (Source: PVsyst). 


\section{TECCIENCIA}

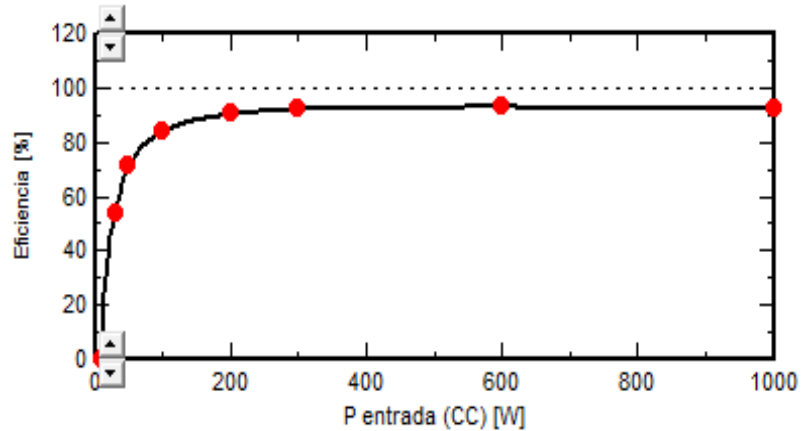

Figure 5. Efficiency of the $1 \mathrm{~kW}$ grid-tied inverter. Source: PVsyst.

Parámetros de la simulación

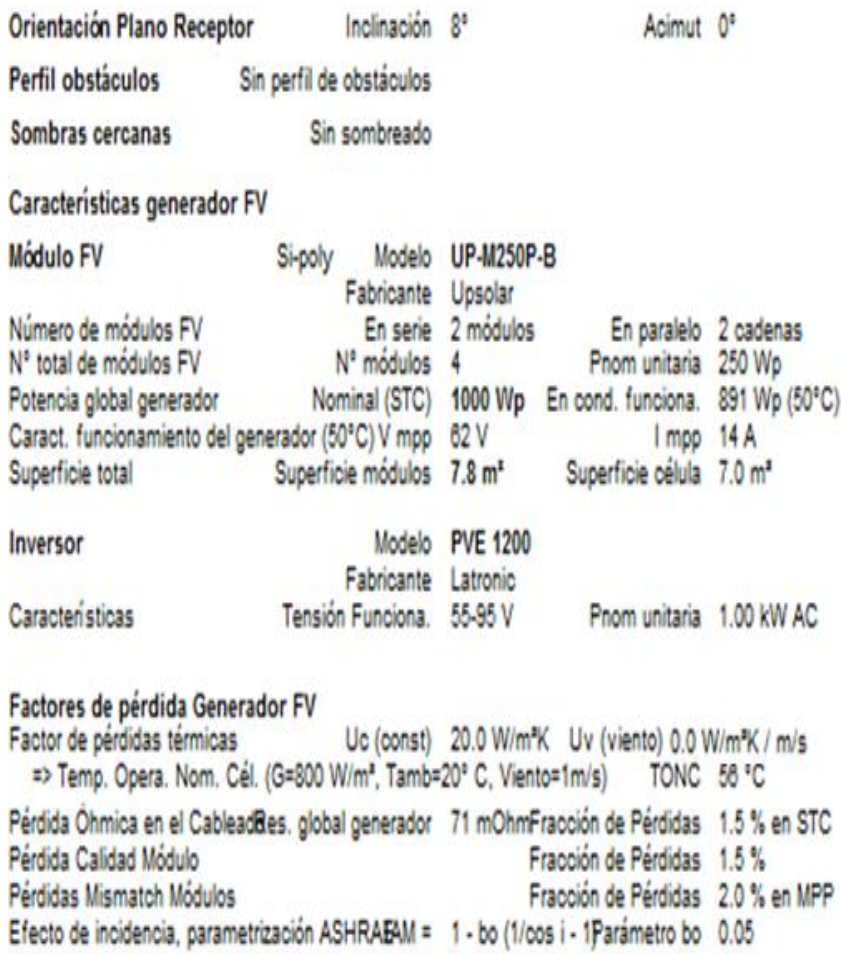

Figure 6. Results of the sizing the $1 \mathrm{~kW}$ installation. Source: PVsyst.
Produociones noirmalizadas (por kWp instalado): Fotencla nominal $1660 \mathrm{WW}$

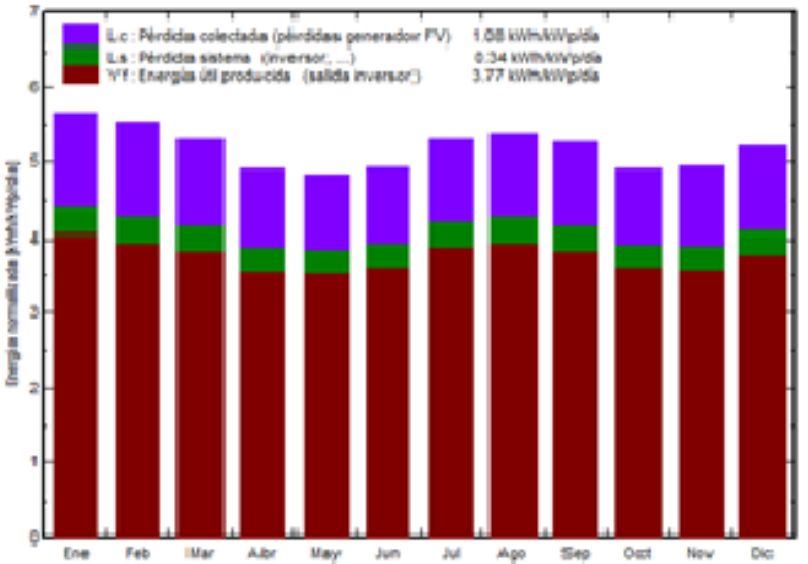

Figure 7. Energy production of the system according to the PVsyst simulation.

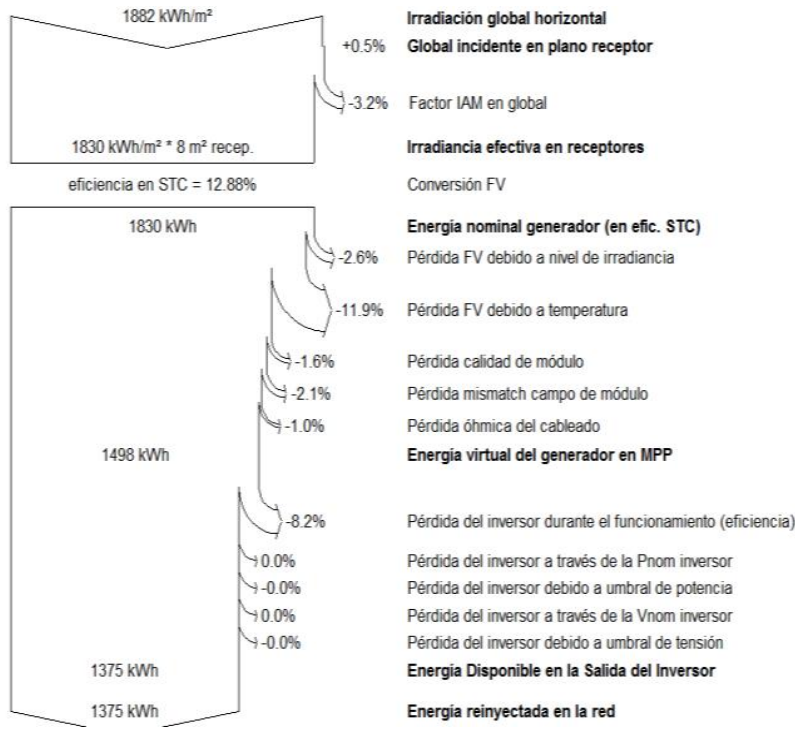

Figure 8. Sankey Diagram of annual losses based on PVsyst simulation. 


\section{TECCIENCLA}

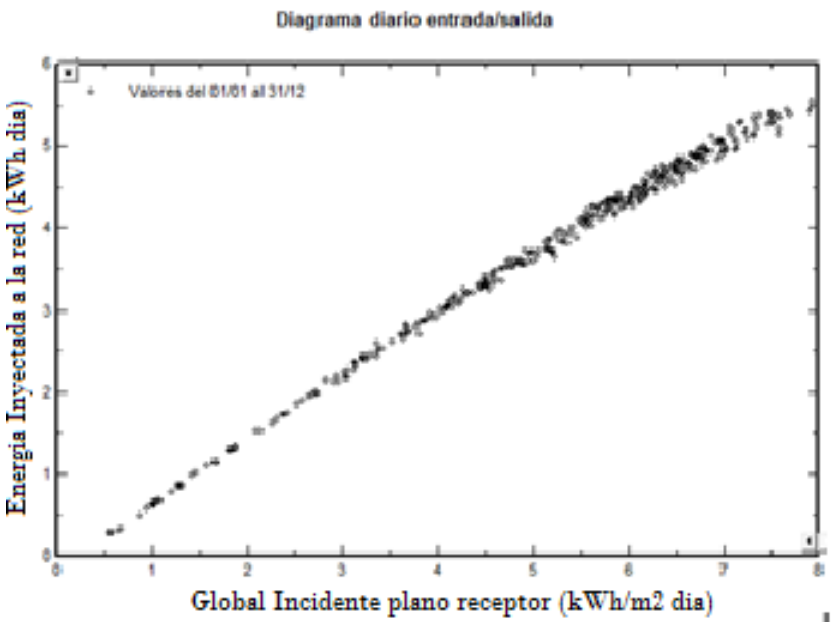

Figure 9. Scatterplot according to the PVsyst simulation.

The results of the sizing of the $1 \mathrm{~kW}$ installation, from PVsyst, are shown in Figure 6, and the performance results are shown in Figures 7, 8, and 9.

\section{Analysis of results}

The report provided by PVsyst details the factors affecting the performance of the PV generator. The temperature exceeded the normal operating temperature of the cell, recorded at $56^{\circ} \mathrm{C}$. In these temperature conditions, photovoltaic modules lose efficiency because, as explained in Figure 4, according to the manufacturer's specifications, the power output decreases at a rate of $0.45 \% /{ }^{\circ} \mathrm{C}$ for this module.

As for the production system, PVsyst gives us the following results:

The result from PVsyst foresees a produced energy of 1375 $\mathrm{kWh} /$ year (as seen in Figure 8) and a performance ratio (PR) of $72.7 \%$. If compared with theoretical data by a simplified conventional method, which gave values of produced energy at $1297.7 \mathrm{kWh} /$ year and a PR of $74 \%$, the difference is minimal, in the order of $5.6 \%$. This shows a great proximity between the data calculated by the theoretical model and the PVsyst validation. This slight difference can be attributed to the accuracy of the PVsyst model when calculating the actual operating points of the modules and inverters, and when including aspects such as wind speed and working temperature, aspects which are explained approximately in the theoretical model.

Figure 9 shows that the system is sized correctly, because there is a good correlation between the irradiance and the energy production, with minimal dispersion.

\section{Conclusions}

This study has shown the dependability of the PVsyst software in the sizing of grid-connected photovoltaic systems.

Comparing the production results calculated by conventional method and the results obtained by the PV system simulation demonstrates a difference of $5.6 \%$, which is not significant, given the precision and detail that the PVsyst provides compared to the theoretical model.

This analysis has validated the reliability of the PVsyst software in sizing and in evaluating the performance of this type of photovoltaic application.

The losses that most affect the performance of crystal technology solar panels are due to the working temperature of the photovoltaic cells. In this case, the low wind speed and the high environmental temperature increase the module temperature and results in a significant increase in system losses.

To conclude this assessment analysis of the grid-tied system, it is important to integrate the theoretical information performed through mathematical calculations with the simulation produced with specialized software (such as PVsyst) and compare it with real information, acquired via the monitoring of photovoltaic systems. This has to be done in order to analyze and detect possible causes that affect the overall performance of the photovoltaic system.

\section{References}

[1] Centrales de energía renovables- José A C González, Roque C Pérez.

[2] S. B. Kjaer, J. K. Pederson, and F. Blaabjerg, "A review of singlephase grid-connected inverters for photovoltaic modules," IEEE Trans. Ind. Appl., vol. 41, no. 5, pp. 1292-1306, Sep./Oct. 2005

[3] Shalwala, R. A., and Bleijs, 1. A. M., "Impact of Grid-Connected PV systems in residential areas in Saudi Arabia", proc. of the 44th International Universities Power Engineering Conference (UPEC), (IEEE 2009), pp.:1-5, 2009

[4] H. Xiao and S. Xie, "Leakage current analytical model and application in single-phase transformerless photovoltaic grid-connected inverter," IEEE Trans. Electromagn. Compat., vol. 52, no. 4, pp. 902-913, Nov. 2010.

[5] E. Lorenzo. Radiación solar y dispositivos fotovoltaicos. Sevilla: Progensa, 2006

[6] E. Lorenzo. "Retratos de la Conexión Fotovoltaica a la Red I". Era Solar (2002).

[7] E. Caramaño. "Edificios fotovoltaicos conectados a la red eléctrica: caracterización y análisis". Tesis doctoral. Instituto de Energía Solar, UPM, 1998.

[8] Shalwala, R. A., and Bleijs, 1. A. M., "Impact of Grid-Connected PV systems in residential areas in Saudi Arabia", proc. of the 44th 


\section{TECCIENCIA}

International Universities Power Engineering Conference (UPEC), (IEEE 2009), pp.:1-5, 2009

[9] Hasimah, A. R., Khalid, M. N., and Mohammad, Y. H., "Assessment of PY cell performance under actual Malaysia operating condition" Power Engineering Conference, AUPEC, Australasian Universities, (IEEE 2009), pp.: 1-5,2009.

[10] Qoaider, L., and Steinbrecht, D., "Photovoltaic systems: A cost competitive option to supply energy to off-grid agricultural communities in arid regions" Applied Energy, vol. 87.2, pp. 427-435, 2010 . 